\title{
Extradural Haematoma in Children: Surgical Experiences and Prospective Analysis of 170 Cases
}

\author{
Çocuklarda Ekstradural Hematom: Cerrabi Deneyim ve 170 Olgunun \\ Analizi
}

Sharif Md Noman KHALED CHOWDHURY, K M TARIKUL ISLAM, Ehsan MAHMOOD, Sk. Sader HOSSAIN

Department of Neurosurgery, Dhaka Medical College, Dhaka, Bangladesh

Correspondence address: S M Noman KHALED CHOWDHURY / E-mail: nomankhaled@yahoo.com

\begin{abstract}
AIM: We present our experiences in the management of extradural haematoma in children which involved an aggressive diagnostic approach, prompt surgical evacuation results in an excellent outcome.

MATERIAL and METHODS: 170 EDH patients who underwent surgery in our department from January 2006 to July 2010 included in this prospective study. Each patient evaluated in term of age, sex, mode of injury, localization of haematoma, clinical presentation, CT findings, operative measures and outcome.

RESULTS: Out of 170 cases $72 \%$, $(n=122)$ were boys and $28 \%,(n=48)$ were girls. The boys to girls ratio was $2.54: 1$. Age ranged from 1.8 to 18 years with a mean age of 9.49 years. Most of the victims are in the $11-18$ years age group $44 \%(n=74)$. The most common mode of injury was fall $41 \%$, ( $n=70)$ followed by Road traffic Accident (RTA) 32\%, $(n=54)$. The most common clinical presentation was altered sensorium $61 \%$, $(n=104)$, followed by headache and/or vomiting $56 \%,(n=96)$. The mortality rate was $8 \%$.

CONCLUSION: EDH is recognized as one of the most rewarding neurosurgical emergencies. It must be diagnosed in the early period of the trauma and evacuated early to prevent potential mortality and morbidity. Different factors affect the outcome of extradural haematoma Surgery including age of the patient, presence of cranial fractures, associated brain lesions and pre-operative neurological condition of patient, duration of time interval between onset of coma and surgical intervention. Better prognosis is seen in patients less than 10 years of age.
\end{abstract}

KEYWORDS: Extradural haematoma, Surgical management, Neurosurgical emergencies

öz

AMAÇ: Etkin bir şekilde ekstradural hematom tanısı konulan ve hızlı bir şekilde opere edilen çocuklarda elde edilen yüz güldürücü sonuçlardan elde edilen deneyimleri aktarmak.

YÖNTEM ve GEREÇ: Prospektif olarak planlanan bu çalışmada, Ocak 2006-Temmuz 2010 döneminde bölümümüzde ameliyat edilen 170 hasta bu çalışmaya dahil edilmiştir. Her bir hasta yaş, cinsiyet, travma şekli, hematomun yerleşimi, klinik bulguları, tomografi bulguları, operasyon şekli ve sonuçları ile incelenmiştir.

BULGULAR: Olguların \% 72'si erkek, \% 28i kızdı. Yaş aralığı 1,8 yıl ile 18 yıl, ortalama yaş 9,49 yıldı. Ekstradural kanamanın en sık görülen nedeni düşmeye bağlı olanlar \%41, (70 olgu , ardından trafik kazaları \%32 (54 olgu) olarak bulundu. Hastalarda en sık olarak bilinç değişikliği \%61 (104 olgu), ardından Başağrısı ve kusma \%56 (96 olgu) olarak bulundu. Seride mortalite oranı $\% 8$ oldu.

SONUÇ: Beyin cerrahisi acil yaklaşımları içerisinde en yüzgüldürücü sonuçları olan patolojilerden birisi de ekstradural hematomlardır. Bu tür hematomlar travmanın erken döneminde tanınmalı ve cerrahi tedavisi mortalite ve morbiditeyi önlemek için en hızlı şekilde yapılmalıdır. Ekstradural hematomların cerrahi sonuçları değişik faktörler tarafından etkilenmektedir; bunlar, hastanın yaşı, kranial kemik kırıklarının olması, beyinde ek lezyonların olması, hastanın ameliyat öncesi klinik durumu ve hastanın komaya giriş süresi ile ameliyata alınış süresi arasında geçen süre gibi etkenler sayılabilir. Yaşı 10'dan küçük olan hastaların prognozu daha iyi olmaktadır.

ANAHTAR SÖZCÜKLER: Ekstradural hematom, Cerrahi yönetim, Beyin cerrahisi aciliyeti

\section{INTRODUCTION}

Extradural haematoma (EDH) is a unique form of neurotrauma, being potentially lethal, yet easily remedied if diagnosed early and promptly treated. The incidence of EDH among traumatic brain injury (TBI) patients has been reported to be in the range of 2.7 to $4 \%$ (7). It has been estimated that EDH represents $2-3 \%$ of all head injuries in the pediatric population (10). The mean age of pediatric patients harboring EDH is between 6 and 10 years and it is even rarer among infants under the age of 12 months $(3,7,10,28)$. 
It is recognized thatEDH in children differ from EDH in adults in that the haematoma may follow a trivial injury, the symptoms are different, the course is more insidious, associated skull fracture is infrequent (16) and these make it difficult to diagnose and often challenging to manage. Furthermore, the criteria for utilizing surgical evacuation vs conservative management have remained ill-defined. Thus, the lack of any guideline regarding the appropriate management of EDH in pediatric patients and particularly in infants makes the management of this specific group of patients all the more complicated (10).

The reported mortality rates of EDH in children are quite different varying between $0 \%$ and $17 \%$ (16). These considerable variations in the outcome and lack of data that provide a clear cut picture of EDH in children prompted us to carry out this study. We present our experiences with 170 cases of acute epidural hematoma in children less than 18 years of age. Here, we also discuss the age-related findings and the differences with adults.

\section{MATERIAL and METHODS}

Between January 2006 and July 2010, 170 patients were surgically managed at the Department of Neurosurgery, Dhaka Medical College \& Hospital. This prospective study includes these patients and categorized them according to age and were divided into four groups, for analysis and comparison of their presentation and management. A meticulous physical examination, with an emphasis on neurological function, was performed on admission. The diagnosis of haematoma was confirmed by CT scanning. In addition, standard epidemiological data including age, sex and mode of injury, presence of skull fracture, presenting clinical features from injury to surgery, preoperative Glasgow Coma Score (GCS) and pupillary reaction to light, presence of other injury, CT findings, localization of haematoma, the effect of injury and timing from injury to surgery were recorded. Surgical decision was determined by the following clinical and radiologic parameters: 1) Unconscious or deterioration of neurological status in patients with a extradural hematoma larger than $20 \mathrm{ml}$, 2) Volume of the hematoma $30 \mathrm{ml}$ even if the patient is awake and free from neurological deficit, 3) Volume of the hematoma $20 \mathrm{ml}$ when located in critical sites, such as posterior cranial fossa or temporal base, 4) midline Shift $>0.5 \mathrm{~cm}$ with deterioration of level of consciousness, 5 ) Increase in the hematoma size.

Patients with spontaneous EDH or EDH of unknown etiology and patients treated conservatively were excluded from current study. Asymptomatic patients, patients presenting only minor symptoms with small haematoma (thickness less than $20 \mathrm{~mm}$ ), patients admitted 24 or more hour after trauma with neurological stable condition were selected for conservative management. These patients were very closely observed clinically by monitoring level of consciousness, focal neurological signs, and vital signs and follow up CT scan was done to asses clot size. We had to operate on 9 such cases when patient's level of consciousness and GCS were deteriorated and repeat $\mathrm{CT}$ scan showed increase in size of haematoma. All the cases were operated on emergency basis. Surgical management consisted of craniotomy under general anesthesia and removal of the underlying hematoma. Outcome was assessed on an outpatient basis. The Glasgow Outcome Scale (GOS) was utilized for evaluating the outcomes.

\section{OBSERVATIONS AND RESULTS}

The results were summarized in the table which illustrates the epidemiology and clinical features of the pediatric patients. Out of 170 patients, $72 \%(n=122)$ were boys and $28 \%(n=48)$ were girls. The boys and girls ratio was $2 \cdot 64: 1$. Age at the time of the accident ranged from 1.8 to 18 years with a mean age of 9.49 years. We found that the frequency of acute traumatic extradural haematoma in children increases with age, and comparatively elder children (age group 11-18 years) were the commonest victims. The most common mode of injury was fall from height $41 \%(n=70)$ followed by road traffic accident (RTA) 32\% ( $n=54)$.The most common clinical presentation was altered sensorium $61 \%(n=104)$, followed by Headache / Vomiting $56 \%(n=96)$. Aside from these, 19\% $(n=32)$ patients had neurological deficit. Early seizures were recorded in $13 \%$ $(n=22)$ children presenting with EDH. The classically described "lucid interval" $i$, e. a patient who is initially unconscious, then wakes up and secondarily deteriorates, was observed in 28 $\%(n=48)$ cases. According to CT finding, temporoparietal region was involved in $34 \%(n=68)$ followed by frontal and parietal region in $29 \%(n=50)$ and $14 \%(n=21)$ respectively. The posterior fossa involvement was very few, just $6 \%$ cases $(n=10) .62 \%,(n=106)$ patients showed skull fractures demonstrated either by x-ray, or CT scan or discovered at the time of operation. Associated extra cranial injuries were present in $32 \%(n=54)$ cases. All the cases were operated on emergency basis and two third of cases (67\%) were operated on within the first 24 hours. Fourteen patients ( $8 \%$ ) died after surgery. Among these 14 patients, 6 had associated brain injuries, 8 cases were deeply unconscious and 9 of these had fixed pupil / pupils at the time of admission.

\section{DISCUSSION}

Only a small number of articles of children extradural haematomas based on surgical experiences and prospective analysis exist in the literature. To the best of our knowledge ours is one of the largest series to date. Traumatic extradural haematoma $(E D H)$ in children have some unique features when compared with those in the adult population. Traumatic extradural haematoma $(E D H)$ in children accounted for $12 \%$ of the 1460 patients with an epidural hematoma operated in our institution in the same period. This lower incidence of acute epidural hematoma in the children compared with adults is also reported in other series and is attributable to the tight adherence of the dura mater to the inner table of the skull $(11,16,24,27)$. In our series, the age of the patients ranged from 1.8 years to 18 years with a mean age of 9.49 years. There were $72 \%$ males and $28 \%$ female patients; the ratio between them was 2:54:1. Our analysis has identified that EDH is more 
Table I: Demographic and Clinical Profile of Traumatic Extradural Haematoma in Children

\begin{tabular}{|c|c|c|}
\hline Features & $\begin{array}{c}\text { Number } \\
\text { (n) }\end{array}$ & Percentages \\
\hline 1. No. of patients & 170 & \\
\hline $\begin{array}{l}\text { 2. Sex } \\
\text { Male } \\
\text { Female } \\
\text { Male: female ratio }\end{array}$ & $\begin{array}{r}122 \\
48\end{array}$ & $\begin{array}{c}72 \\
28 \\
2.54: 1\end{array}$ \\
\hline $\begin{array}{l}\text { 3. Age (mean age } 9.49 \text {; range } \\
1.8 \text { to } 18 \text { years) } \\
0 \text { to } 2 \text { years } \\
3 \text { to } 5 \text { years } \\
6 \text { to } 10 \text { years } \\
11 \text { to } 18 \text { years }\end{array}$ & $\begin{array}{r}8 \\
28 \\
60 \\
74\end{array}$ & $\begin{array}{r}5 \\
16 \\
35 \\
44\end{array}$ \\
\hline $\begin{array}{l}\text { 4. Mode of Injury } \\
\text { Fall from height } \\
\text { RTA } \\
\text { Assaults } \\
\text { Fall of heavy weight on head }\end{array}$ & $\begin{array}{l}70 \\
54 \\
36 \\
10\end{array}$ & $\begin{array}{r}41 \\
32 \\
21 \\
6\end{array}$ \\
\hline $\begin{array}{l}\text { 5. Common Site of Haematoma } \\
\text { Temporoparietal } \\
\text { Frontal } \\
\text { Parietal } \\
\text { Temporal } \\
\text { Posterior fossa } \\
\text { Occipital }\end{array}$ & $\begin{array}{r}68 \\
50 \\
21 \\
21 \\
10 \\
4\end{array}$ & $\begin{array}{r}34 \\
29 \\
14 \\
12 \\
6 \\
2\end{array}$ \\
\hline $\begin{array}{l}\text { 6. Clinical Presentations } \\
\text { Altered sensorium } \\
\text { Headache /Vomiting } \\
\text { Lucid interval } \\
\text { Neurodeficit (hemiparesis) } \\
\text { Seizure }\end{array}$ & $\begin{array}{r}104 \\
96 \\
48 \\
32 \\
22\end{array}$ & $\begin{array}{l}61 \\
56 \\
28 \\
19 \\
13\end{array}$ \\
\hline 7. Cerebral oedema & 64 & 38 \\
\hline $\begin{array}{l}\text { 8. Associated injuries } \\
\text { Skull Fracture } \\
\text { Contusion / ICH Acute } \\
\text { Subdural Haematoma }\end{array}$ & $\begin{array}{r}106 \\
42 \\
10\end{array}$ & $\begin{array}{r}62 \\
25 \\
6\end{array}$ \\
\hline $\begin{array}{l}\text { 9. Extra cranial injuries sustained } \\
\text { Long bone fracture } \\
\text { Maxillofacial injury }\end{array}$ & $\begin{array}{l}32 \\
22\end{array}$ & $\begin{array}{l}19 \\
13\end{array}$ \\
\hline $\begin{array}{l}\text { 10. Time interval between } \\
\text { trauma and operation (Hours) } \\
\begin{array}{l}0-12 \\
13-24 \\
25-48\end{array}\end{array}$ & $\begin{array}{l}22 \\
92 \\
56\end{array}$ & $\begin{array}{l}13 \\
54 \\
33\end{array}$ \\
\hline Mortality rate & 14 & 8 \\
\hline
\end{tabular}

frequent in 11 years of age or above among children (44\%). Only $5 \%$ of the victims were infants. These data is correlated with other reported series of EDH in children $(9,12,14,21,24)$. This is due to the high-velocity trauma mechanism in the older age group (27). In this series majority of patients were boys $(72 \%)$. It is similar to other reported series of $E D H$ in children $(11,14,20,22)$ and these trends were observed even in infants (67\%). It was reflecting the natural tendency of boys to indulge in risky play activities.

In our series, falls were the predominant modes of injury (41\%) followed by RTA (32\%). Out of 70 victims of fall, (33/70) were in domestic, $(28 / 70)$ in sports and recreation; and $(9 / 70)$ were in work. Similar results have been reported by other authors $(14,20,23,24,27)$ but Dhellemmes found that $64 \%$ patients with EDH had been involved RTA and other causes had occurred less frequently (11). RTA is the commonest mode of injury in adult also $(9,16)$. So, this series showed a significant difference in the mechanism of injury between children and adults.

The classical presentation of traumatic extradural haematoma, as described in the majority of text books was the exception rather than rule. In this series, most patients (61\%) had altered sensorium and we strongly believe that this is the most significant sign of EDH in Children. It is supported in other reported series also $(11,14,21) .56 \%$ Children had headache associated with persistent vomiting. It is nonspecific but important clinical sign. In our series we evaluated other clinical signs such as hemiparesis (19\%) and pupil dilatation (22\%). The classically described "lucid interval" was observed in $28 \%$ cases in our series. It is almost similar to Ersahin et al (13) who had found lucid interval in $37 \%$ cases but was contradictory to Hanci et al (14) who discovered it was only in 11.125 cases. Epilepsy is a recognized complication of EDH, especially in the presence of associated intradural (ID) damage (16). In our series, early seizure was noted in $13 \%$ cases. Our data is almost double than Ben Abraham et al, (3) who reported early seizure in $8 \%$ of pediatrics patients only.

In this series, there was a significant difference between children and adults in the clinical course. Simpson et al (29) pointed out that diagnosis of EDH in a child may not be made until early clinical feature of raised ICP is present. Young children can tolerate an acute increase in intracranial pressure better than adults because they have unfused cranial sutures, open fontanelles, large extracerebral spaces and basal cisterns, and moreover the origin of EDH in children is often venous whereas in adults, it is mainly caused by an arterial bleeding (2). In our series, we evaluated clinical signs as expected. Accordingly early detection of the lesion is critical. The sign / symptoms were nonspecific in majority of cases. Based on clinical findings early diagnosis was established only in small percentage of cases. Evolution over time influences the treatment of EDH significantly. We believe that CT scan of head should be done routinely in suspected case as early diagnosis of EDH is mandatory for good recovery as radiological changes always occur earlier than clinical changes and should be monitor to predict the clinical progression $(4,5,29)$.

In this series, the temporoparietal region (34\%) was the commonest site followed by frontal region. It is similar to 
Hanci et al (14) who had opinion that EDH originating in the fronto temporal region does not spread to the frontal region. A possible explanation is the adherence of dura at the suture line (8). In our series, as regard location, frontal haematomas have shown a better prognosis and a slower course than convexity haematomas. It is contrary to Mohanty et al (23) who found that the site of haematoma had no correlation with the final outcome. We also found that the GCS score and the associated parenchymal injuries had a strong correlation with the outcome both in adult and children. It is in strong agreement with Mohanty et al. (23) experiences.

In our series, cranial fractures were present in $62 \%$ patients' with significantly lower mortality rate. In many reported series, cranial fractures were in between $70-95 \%(7,15,17,18,19,25,30)$. The impact of fracture on outcome is controversial. Kuday et al. (18) observed a significant relationship between cranial fractures and adverse outcome in 115 patients undergoing surgery for $\mathrm{EDH}$. Lee et al. (20) did not see this relationship in a series of 200 patients managed similarly. But Rivas et al. (26) reported a significantly lower mortality rate in patients with cranial fractures which is in strong agreement with our findings. However, incidence of skull fracture in children in this series is lower than adults (9).

The rate and type of associated extracranial injuries (32\%) in our series is higher than in the study by Duthie et al (12). 5\% of children in their study had associated extracranial injuries.

The presence of CT scan evidence of a concomitant intradural (ID) injury is recognised as a poor prognostic factor (16). In our series, associated brain injuries discovered in $31 \%$ cases. These are predominantly contusions, intra-cerebral haemorrhage and subdural haematomas. The incidence of associated lesion in reported series is less in pediatrics age group $(7,8,16,23,25)$. SDH and / or parenchymal injuries in association with EDH lower the chance of good outcome (7). Like our series, in children the most common concomitant intradural abnormality was brain edema, while in adults it was hemorrhagic contusion (16).

Despite a steady decline in mortality, in this series the mortality rate was $8 \%$. Among these, $43 \%$ had associated brain injuries, $57 \%$ cases were deeply unconscious and $64 \%$ victims of these had fixed pupil / pupils at the time of admission. Mazza et al. (21) discovered associated brain lesions in $40 \%$ of his cases, over all mortality rate was $17 \%$, with $14 \%$ operative mortality. Ersahin et al. (13) found $10 \%$ overall mortality, with mortality rate in the CT and plain x-ray groups $6 \%$ and $16 \%$ respectively. In this series, we observed that outcome showed an age-related discontinuity because the prognosis worsens as age increases. The mortality rate in children was less than in adult series (9) but $0 \%$ mortality as proposed by Ammirati (1) and Bricolo (6) should be the goal of EDH surgery.

\section{CONCLUSION}

Extradural haematoma in children is one of the most rewarding neurosurgical emergencies that must be recognized and treated immediately. An extradural haematoma must be considered in any child whose condition does not improve rapidly following a relatively mild head injury and it can be enlarged while child is under supervision. It is not rare for EDH to develop and present in delayed fashion. Timely diagnosis and prompt surgical evacuation of the haematoma results in excellent outcome. Our experiences of 170 surgically managed cases produced such a result. Many factors affect the outcome of extradural haematoma surgery. In addition, presence of cranial fractures, associated brain lesions and pre-operative neurological status of patient, duration of time interval between onset of coma and surgical intervention determine the outcome of patient. Morbidity and mortality have also been shown to be affected by age, with better prognosis in patients under 10 years of age.

\section{REFERENCES}

1. Ammirati $\mathrm{M}$, Tomita $\mathrm{T}$ : Epidural hematomas in infancy and childhood. J Pediatric Neuroscience 1:123-128, 1985

2. Balmer B, Boltshauser E, Altermatt $S$, Gobet R: Conservative management of significant epidural haematomas in children. Childs Nerv Syst 22:363-367, 2006

3. Ben Abraham R, Lahat E, Sheinman G, Feldman Z, Barzilai A, Harel R, Barzilay Z, Paret, G: Metabolic and clinical markers of prognosis in the era of CT imaging in children with epidural haematoma. Pediatr Neurosurg 33:70 75, 2000

4. Bor-Sen-Shu E, Aguiar PH, Almedida Leme RJ, Mandel M, Andrade AF, Marino R Jr: Epidural hematomas in the posterior cranial fossa. Neurosurg 16(2), 2004

5. Bozbuga M, Izgi N, Polat G, Gurel I: Posterior fossa epidural hematomas: Observation on a series of 73 cases. Neurosurg Rev 22:34-40,1999

6. Bricolo AP, Pasut LM: Extradural haematoma: Toward zero mortality. A prospective study. Neurosurgery 14:8-12, 1984

7. Bullock MR, Chesnut R, Ghajar J, Gordon D, Hartl R, Newell DW, Servadei F, Walters BC, Wilberger JE: Surgical management of acute epidural haematomas. Neurosurgery 58(3):S2-7-S2-15, 2008

8. Choux M, Grisoli F, Peragut JC: Extra dural haematoma in children. Child's Brain 1:337 -347, 1975

9. Chowdhury Noman Khaled SM, Raihan MZ, Chowdhury FH, Ashadullah ATM, Sarkar MH, Hossain SS: Surgical management of traumatic extradural haematoma: Experiences with 610 patients and prospective analysis. Indian Journal of Neurotrauma (IJNT) 5(2):75-79, 2008

10. Ciurea AV, Kapsalaki EZ, Coman TC, Roberts JL, Robinson III JS, Tascu A, Brehar F, Fountas KN: Supratentorial epidural hematoma of traumatic etiology in infants. Childs Nerv Syst 23:335-341, 2007

11. Dhellemmes $P$, Lejeune JP, Christianes JL, Combelles G: Traumatic extradural haematoma in infancy and childhood: Experience with 144 cases. J Neurosurg 62:861-864,1985

12. Duthie G, Reaper J, Tyagi A, Crimmins D and Chumas P: Extradural haematomas in children: A 10 year review. B J Neurosurg 23(6):596-600, 2009 
13. Ersahin $Y$, Mutluer S, Guzelbag E: Extradural Haematoma analysis of 146 cases. Child's Nerv Syst 9:96-99,1993

14. Hanci M, Uzan M, Kuday C, Sarioglu A C, Akar Z, Canbaz B, Erdinclear $P$, Akcura S: Epidural Haematomas in infancy and childhood: Report of 54 cases. Turkis Neurosurgery 4:73-76, 1994

15. Hunt J, Hill D, Besser M, West R, Roncal S: Outcome of patient with neurotrauma: The effect of a recognized trauma system. Aust N Z J Surg 65:83-86, 1996

16. Jamjoom A, Cummins B, Jamjoom ZA: Clinical characteristics of traumatic Extradural haematoma: A comparison between children and adults. Neurosurg Rev 17:277-281, 1994

17. Jamjoom A: The difference in the outcome of surgery for traumatic Extradural Haematoma between patients who are admitted directly to the neurosurgical unit and those referred from another hospital. Neurosurg Rev 20:227-230, 1997

18. Kuday C, Uzan M, Hanci M: Statistical analysis of the factors affecting the outcome of Extradural Haematomas: 115 cases. Acta Neurochir (Wien) 131: 203-206, 1994

19. Lee EJ, Hung YC, Wang LC, Chung KC, and Chen HH: Factors influencing the functional outcome of patients with acute epidural haematomas. Analysis of 200 patients undergoing surgery. J Trauma 45:946-952,1998

20. Leggate JRS, Lopes Ramos N, Genetori I, Lena G, Choux M: Extradural haematoma in infancy, B J Neurosurg 3:533-540, 1989

21. Mazza C, Pasqualin A, Feriotti G, Da Pian R: Traumatic Extradural Haematoma In children: Experience with 62 cases. Acta Neurochir 65:67-80, 1982
22. Milza PG, Nardi PV, Gigla G, La Motta A: Extradural haematoma in infancy and childhood. Report on 176 cases. J Pediatric Neuroscience 5:117-122, 1985

23. Mohanty A, Kolluri VR, Subbakrishna DK, Satish S, Mouli BA, Das BS: Prognosis of extradural haematomas in children. Pediatr Neurosurg 23:57-63, 1995

24. Pasaoglu A, Orhan C, Koc K, Selcuklu A, Akdemir A, Uzunoglu $\mathrm{H}$ : Traumatic extra dural haematoma in paediatric age group. Acta Neurochir (wien) 106:136-139, 1990

25. Pillay R, Peter J: Extradural haematoma in children. S Afr Med J 85:672-674, 1995

26. Rivas JJ, Lobato RD, Sarabia R, Cordobes F, Cabrera A, Gomez P: Extradural haematoma: An analysis of factors influencing the ocourses of 161 patients. J Neurosurgery 23:44-51, 1988

27. Rocchi G, Caroli EM, Raco A, Salvati M, Delfini R: Traumatic epidural hematoma in children. J Child Neurol 20: 569-572, 2005

28. Schutzman SA, Barnes PD, Mantello M, Scoot RM: Epidural haematoma in children. Ann Emerg Med 22:535-541,1993

29. Simpson DA, Cockington RA, Hanieh A, Raftos J, Reilly PL: Head injuries in infant and young children: The value of paediatric coma scale. Review of literature and report on study.Child Nerv Syst 7:183-190, 1991

30. Sullivan TP, Jarvik JG, Cohen WA: Follow-up of conservatively managed epidural haematomas: Implications for timing of repeat CT. AJNR AM J Neuroradiol 20:107-113, 1999 